\title{
INFLUENCE OF PHOSPHOMIDE, A CHEMICAL MUTAGEN, ON AGROBIOLOGICAL SIGNS OF SOFT SPRING WHEAT Triticum aestivum L.
}

\section{N.A. BOME1, L.I. WEISFELD ${ }^{2}$, E.V. BABAEV ${ }^{3}$, A.Ya. BOME ${ }^{4}$, N.N. KOLOKOLOVA ${ }^{1}$}

${ }^{1}$ Tyumen State University, 6, ul. Volodarskogo, Tyumen, 625003 Russia, e-mail bomena@mail.ru (corresponding author);

${ }^{2}$ N.M. Emanuel Institute of Biochemical Physics RAS, Federal Agency of Scientific Organizations, 4, ul. Kosygina, Moscow, 119334 Russia, e-mail liv11@yandex.ru;

${ }^{3}$ M.V. Lomonosov Moscow State University, Biological Faculty, 1, Leninskie gory, Moscow, 119991 Russia, e-mail babaev@org.chem.msu.ru;

${ }^{4}$ Federal Research Center the N.I. Vavilov All-Russian Institute of Plant Genetic Resources, Federal Agency of Scientific Organizations, 42, ul. Bol'shaya Morskaya, St. Petersburg, 190000 Russia, e-mail genbank.d@gmail.com ORCID:

Bome N.A. orcid.org/0000-0002-8496-5365

Weisfeld L.I. orcid.org/0000-0002-8449-3679

Bome A.Ya. orcid.org/0000-0001-6999-8997

Babaev E.V. orcid.org/0000-0001-8727-7763

Kolokolova N.N. orcid.org/0000-0002-6833-6462

The authors declare no conflict of interests

Acknowledgements:

The authors thank Dr N.A. Provorov (ARRIAM, St. Petersburg) for the analysis of the article and helpful discussion on specific issues of experimental mutagenesis

Received October 24, 2016

\section{Abstract}

The method of chemical mutagenesis allows in a relatively short time to obtain a material with new features and properties, including completely new mutations. The effectiveness of the application of the method for the creation of selection valuable forms of plants in various soil and climatic conditions is shown in the works of a number of authors. The purpose of this work was to study the effect of the mutagen namely phosphomide in different concentrations on the agrobiological characters at the hybrid form and the initial cultivars of spring soft wheat (Triticum aestivun L.). Two domestic cultivars (Scant 1, Scant 3, var. lutescens) and three foreign cultivars (Cara, var. erythrospermum; Hybrid, var. ferrugineum; Lutescens 70, var. lutescens) were the source material. A preliminary study of the varieties was carried out in 2006-2008. In 2009, hybrid combinations involving these varieties were obtained using incomplete diallel crosses and forced pollination. The efficacy of phosphomide, a chemical mutagen, at concentrations of 0.002 and $0.01 \%$ was studied in two varieties (Cara and Scant 3) and $\mathrm{F}_{4}$ hybrid (Cara $\times$ Scant 3). For the treatment, the seeds were soaked in phosphomide solutions for 3 hours, and the control seeds were soaked in distilled water. Germination energy and morphometric parameters of the seedlings were evaluated in laboratory tests to calculate the growth inhibition indices. In the spring 2014, 25 mutagen-treated seeds were sown in the field (Biostation of Tyumen State University, Tyumen Province) in 4-fold replication separately for each variant of treatment to obtain $M_{1}$ generation. From individual $M_{1}$ plants were separately derived $\mathrm{M}_{2}$ generation. Resistance of the specimens toward leaf fungus diseases (powdery mildew, leaf rust and spotting) was assessed under natural infection development (Biostation of Tyumen State University, Tyumen Province) during the entire vegetation period, from appearance of the symptoms till the leaves dried up, using laboratory tests for specific pathogen identification. The results obtained suggest that the use of phosphomide promotes diversity of the breeding material. In the first generation $\left(\mathrm{M}_{1}\right)$, there was an inhibitory effect of phosphomide on field wheat germination and the morphometric parameters of seedlings (the length of roots and shoots) which depended on the mutagen concentration. The seedlings showed the least tolerance to phosphomide as to the number of germinal roots. The effect of stimulation compared to the control occurred in the hybrid combination Cara $\times$ Scant 3 as to seed germination energy indices (by $5.9 \%$ ) in the laboratory tests and plant viability in the field during the growing season (by 14.0-80.0\%). The mutagen increased significantly the grain weight per $1 \mathrm{~m}^{2}$ in the hybrid (by $16.0 \%$ ) while the grain yield in the varieties Cara and Scant 3 decreased by 67.0 and $57.0 \%$, respectively. In high concentration $(0.01 \%)$ the mutagen reduced resistance to powdery mildew and brown rust in the varieties whereas in the hybrid at the same concentration the susceptibility to powdery mildew decreased, and to brown rust - increased. The phenotypic changes in $\mathbf{M}_{2}$ were assessed according to the morphology of the ear, stem, leaves (color, pubescence, shape, size) and biological properties (late ripening, early ripening, winter type plants). In total, there were 12 types described. Plants with a large ear, strong stems, stunted and 
dwarfs were more common in the hybrid (13.6-20.0\% of the total number of modified forms). The varieties often produced early ripening forms (16.4-24.2\%). The proportion of families with altered plants in the varieties was $5.3 \%$ less than in the hybrid. The highest rate of modifications in the varieties and the hybrid was influenced by $0.01 \%$ concentration. Thus, it is shown that phosphomide at concentrations of 0.002 and $0.01 \%$ is effective to improve agronomically important characteristics in the varieties and intraspecies hybrid of soft spring wheat.

Keywords: spring wheat, chemical mutagenesis, transgression, phytopathogens, mutants

The basis of food and bioresource safety is the genetic resources of plants. By the middle of the 21st century, up to $60 \%$ of their species composition can be lost $[1,2]$. The loss of plant resources is considered as one of the ecological crisis factor of the biosphere [3]; therefore, a strategy for the conservation and sustainable use of the biodiversity is necessary, including its expansion by classical and modern methods.

The traditional method of chemical mutagenesis allows organisms with new characteristics and properties to be obtained in a relatively short time [4]. It is still widely and effectively used to create valuable plant forms in various soil and climatic conditions, including in Western Siberia [5-8]. The development of mutational selection can be associated both with the use of known chemical supermutagens (N-nitrosomethylurea, N-nitrosoethylurea, ethyleneimine) and with the discovery of new highly active substances [9]. These include chiral stereoisomers used in the herbicide, insecticide and fungicide production industry [10]. The mutagenic effect is also shown by alkylating agents, nitrous acid, nitrogen oxide, analogues of nitrogenous bases and related compounds, antibiotics, intercalating agents and topoisomerases of poisons [11].

Diethylenimid-2-amidopyrimidylphosphoric acid (phosphomide) consists of two groups of ethyleneimine combined with phosphorus and a pyrimidine base. Ethyleneimine causes mutations; the pyrimidine base is incorporated into the chromosome during DNA synthesis, determining effect specificity. The mutagenic effect of phosphomide [12] was studied earlier on the Crepis capillaris L. model. Studies with Triticum aestivum L. have not been carried out. The necessary working step in experimental mutagenesis is determining the ranges of concentrations in which the desired effects are possible.

The specificity of the mutagenic effect of phosphomide on varieties (Cara and Scant 3) and the hybrid form of spring soft wheat has been studied for the first time in this work; and the effect of a chemical mutagen gene on the variability of population and individual characteristics has been determined.

Our goal was to study the effect of phosphomide in different concentrations on the agrobiological traits of spring soft wheat.

Technique. Soft wheat (Triticum aestivum L.) was represented by five varieties from VIR World collection (N.I. Vavilov All-Russia Institute of Plant Genetic Resources, St. Petersburg) of Russian origin (Scant 1 and Scant 3, var. lutescens, Russia, Tyumen Province), and of foreign origin (Cara, var. erythrospermum, Mexico; Hybrid, var. ferrugineum, Mexico; Lutescens 70, var. lutescens, Kazakhstan). A preliminary study of the varieties was carried out in 2006-2008 (Tyumen VIR Reference Station) [13]. In 2009, hybrid combinations involving these varieties were obtained using incomplete diallel crosses and forced pollination [14].

Comparative field evaluation of hybrid and parental forms was carried out in 2010-2014 when planting in blocks with $10 \times 20 \mathrm{~cm}$ feeding area of each plant in the first stage $\left(F_{1}\right)$ and then in subsequent sowing $\left(F_{2}, F_{3}\right.$, etc. $)$ by families (offspring of one plant). For each hybrid combination in $F_{1}$, more than 50 plants were analyzed, in $\mathrm{F}_{2}$ and subsequent generations 200 plants and more were tested. 
The efficacy of phosphomide at concentrations of 0.002 and $0.01 \%$ was studied in two varieties (Cara and Scant 3) and in $\mathrm{F}_{4}$ hybrid (Cara $\times$ Scant 3). The seeds were submerged in phosphomide solutions for 3 hours. The control was the seeds submerged in distilled water. A total of 300 seeds of each variety and a hybrid combination (100 in each variant of the experiment, i.e. the control, $0.002 \%$ mutagen, $0.01 \%$ mutagen) for laboratory and 300 seeds for field studies were used.

The germination energy and the morphometric parameters of the seedlings were evaluated in laboratory conditions [15]. Growth inhibition indices were calculated as the ratio of the length of the roots, shoots and number of roots of the seedlings under the action of the mutagen and in the control.

The generation $\mathrm{M}_{1}$ was studied in field experiments (Lake Kuchak Biostation of Tyumen State University, Tyumen region). In the spring of 2014, 25 seeds were sown in 4-fold replication separately for each mutagen treatment. The $\mathrm{M}_{2}$ progeny were obtained individually from each plant. Resistance of specimens to fungal diseases (powdery mildew, leaf rust and leaf spotting) was assessed under natural infection development during the entire growing season (from the appearance of the first symptoms of the disease till the leaves dried up) [16]. The pathogen was identified using microscopy and moist chamber method [17]. In $\mathrm{M}_{2}$, phenotypic changes were assessed according to the morphological features of the ear, stem and leaves (color, pubescence, shape and size) and biological properties (late ripening, early ripening and winter type plants).

Data processing was carried out using Microsoft Excel spreadsheet and STATISTICA 6.0 software (StatSoft Inc., USA). For quantitative traits, the mean values $\left(X_{\mathrm{m}}\right)$ and the error of the mean $\left(S_{x}\right)$ are presented in the tables; for qualitative traits, the value $(X)$ and the indicator of traits variability $(S)$ are shown. The significance of the differences between the mean values of the variants was estimated using the Student $t$-test.

Result. The variety Cara belonged to the group of undersized varieties (plant length of $54.9 \mathrm{~cm}$ ), and was resistant to lodging (7-9 points). The vegetation period was 77 days like that in Hybrid, but was 5-6 days less then in Scant 1, Scant 3 and Lutescens 70. This variety was resistant to powdery mildew and, according to GRIS (Genetic Resources Information System for Wheat and Triticale), carries $\operatorname{Lr} 13$ gene for resistance to rust a stable allelic state. The Hybrid variety showed high adaptive properties in the extremely unfavorable meteorological conditions of 2008. During the seeds germination and the shoots formation, the amount of precipitation was $68.6 \%$ of the norm, and the average daily air temperature was $0.5^{\circ} \mathrm{C}$ above the multiyear average; there was an active fly-out of the Osinosoma frit L. The variety was characterized by high drought resistance ( 7 points) and medium resistance to pest damage ( 5 points). The varieties Scant 1, Scant 3 and Lutescens 70 are included in the State Register of Selection Achievements approved for use in the 10th West Siberian region of Russia. These varieties are medium-ripening (82-83 days), with high field germination of seeds and productive tillering, as well as moderate susceptibility to diseases.

Based on the study of 10 combinations of intraspecific crosses $\left(F_{1}-F_{4}\right)$, the hybrid Cara $\times$ Scant 3 was selected according to combinational ability, the character of gene interaction and dominance in $\mathrm{F}_{1}$, transgression and heritability in $F_{2}$. Its high productivity was confirmed by ecological testing of hybrids $F_{4}$ and $\mathrm{F}_{5}$ in three geographical locations essentially differing in climatic conditions: the experimental field of Lake Kuchak Biostation (Tyumen State University, Tyumen region, Russia), the Land of Baden-Württemberg (experimental field of the Waldorf School, Germany), and Lower Saxony (Experimental Station Waldhof, Germany). 
In 2013-2014, biological productivity of the best line from Cara $\times$ Scant 3 hybrid combination exceeded the standards by $62.2 \%$ in Tyumen region (Novosibirskaya 15 and Irgin varieties), and by $44.1 \%$ in Baden-Württemberg (Ashby and Scirocco varieties). In Lower Saxony, no advantages appeared compared to Eminent and Granus varieties [18]. The hybrid was characterized by high resistance to spotting (Alternaria spp. and Helminthosporium spp.) and brown rust [P. recondita Rob. ex. Desm f. sp. tritici Eriks. (=P. triticina Eriks.)].

The possibility of using recombination and mutational variability was considered to expand the biodiversity of $T$. aestivum L. One of the main criteria for the successful use of the mutagen of phosphomide was the proportion of modified plants. In total, $1238 \mathrm{M}_{2}$ families for Cara and Scant 3 varieties and 636 families of the Cara $\times$ Scant 3 hybrid were analyzed (Table 1 ).

1. Effectiveness of phosphomide mutagenesis of spring soft wheat (Triticum aestivum $\mathbf{L}$.) estimated in $\mathbf{M}_{2}$ generation $\left(X_{\mathrm{m}} \pm S_{x}\right.$, Biostation of Tyumen State University, Tyumen region, 2014; field tests)

\begin{tabular}{l|c|c|c|c|c|c}
\hline \multirow{2}{*}{$\begin{array}{l}\text { Concentration } \\
\text { of mutagen, \% }\end{array}$} & \multicolumn{2}{|c|}{ Cara and Scant 3 varieties, families } & \multicolumn{3}{|c}{ Hybrid, families } \\
\cline { 2 - 3 } & \multicolumn{2}{|c|}{ total number } & \multirow{2}{*}{ mutants, \% } & \multicolumn{2}{|c|}{ total number } & \multirow{2}{*}{ mutants, \% } \\
\cline { 2 - 3 } \cline { 5 - 6 } & tested & mutant & & tested & mutant & \\
\hline Control & 329 & 12 & $72.6 \pm 1.03$ & 120 & 9 & $7.5 \pm 2.40$ \\
0.002 & 550 & 64 & $13.1 \pm 1.44$ & 272 & 27 & $9.9 \pm 3.28$ \\
0.01 & 359 & 64.08 & 244 & 74 & $30.3 \pm 2.95$ \\
\hline
\end{tabular}

The genotypic features of varieties and a hybrid on the relative output of valuable forms could be established based on response to different doses of the mutagen. The greatest number of mutants, both in the parental varieties and in the hybrid, was found at a mutagen concentration of $0.01 \%$.

The hybrid significantly differed from the varieties on spontaneous mutation frequency (3.6\% for the populations of the varieties, while among hybrid families mutant plants were 2 times more frequent and reached up to $7.2 \%$ ).

Phenotypic mutations in variants with the use of a chemical mutagen proved to be quite diverse. The following valuable types were distinguished in $\mathrm{M}_{2}$ : tall, low-growth, dwarfs, large-sized, winter-type plants, late ripening, early ripening, with a wide flag leaf, with altered shape and color of spike (spelled, pyramidal, yellow) and with strong straw. In the hybrid form, 8 mutation types of 12 detected were observed. The greatest frequency of the mutagen forms $(30.33 \%)$ was found in the hybrid at $0.01 \%$ phosphomide concentration, and in Cara variety $(15.31 \%)$ at $0.002 \%$ phosphomide concentration. Tall plants with a large ear, early or late maturation were recorded more often, plants with a modified shape of the ear were less often. Hybrid plants were mostly large-sized (ear length 16.5-21.8 cm) (20.0\%); tall (89.3-103.5 cm in height) (18.2\%); with a solid straw (resistance to lodging 9 points) $(13.6 \%$ ); undersized and dwarfs (39.8-61.2 cm in height) (16.4\%). Early-maturing forms (3-5 days earlier than in the control) appeared in a larger number in the Cara and Scant 3 varieties (24.2 and $12.3 \%$, respectively). A speltoid spike was found in five $\mathrm{M}_{2}$ plants grown from seeds treated with $0.01 \%$ phosphomide and tested in $\mathrm{M}_{3}$. These mutations were not revealed in $\mathrm{M}_{1}$ despite the fact that they are dominant and semi-dominant. Grain in speltoid spikes is characterized by increased protein content [19]; speltoids have been cytogenetically studied in the mutants in detail [20]. The observed differences in the frequency and diversity of the mutant forms in the hybrid and the initial varieties may be related to their susceptibility to the mutagen.

To differentiate the varieties and the hybrid on their response to mutagen, we estimated root and shoot growth in the laboratory experiment and calculated the indices of growth inhibition. The indices, as a criterion of plant re- 
sponse to stressors (low temperatures, aluminum ions, fluorides, lead nitrates, oil pollution, etc.), are widely described [21-23]. In our experiment, the number of germinal roots in seedlings reflects their tolerance to phosphomide (Table 2). Significant differences from the control were found only in Scant 3 variety at $0.01 \%$ mutagen concentration when the root number index amounted to 0.47 , while in other variants of mutagenesis it reached 0.85-0.99.

2. Morphometric parameters of spring soft wheat (Triticum aestivum L.) seedlings in $M_{1}$ generation after seed treatment with different concentrations of phosphomide (laboratory experiment)

\begin{tabular}{|c|c|c|c|c|c|c|c|}
\hline \multirow{2}{*}{$\begin{array}{l}\text { Concentration, } \\
\%\end{array}$} & \multirow[t]{2}{*}{ Samples } & \multicolumn{2}{|c|}{$\begin{array}{l}\text { Number of germinal } \\
\text { roots }\end{array}$} & \multicolumn{2}{|c|}{ Shoot length } & \multicolumn{2}{|c|}{ Root length } \\
\hline & & $X_{\mathrm{m}} \pm S_{x}$ & RNI & $X_{\mathrm{m}} \pm S_{x}, \mathrm{~mm}$ & SLI & $X_{\mathrm{m}} \pm S_{x}, \mathrm{~mm}$ & RLI \\
\hline \multirow[t]{3}{*}{ Control } & Cara & $2.84 \pm 0.12$ & 1.00 & $8.21 \pm 0.78$ & 1.00 & $21.42 \pm 1.09$ & 1.00 \\
\hline & Cara $\times$ Scant 3 & $3.82 \pm 0.32$ & 1.00 & $11.35 \pm 0.80$ & 1.00 & $20.09 \pm 1.40$ & 1.00 \\
\hline & Scant 3 & $3.82 \pm 0.21$ & 1.00 & $9.18 \pm 0.85$ & 1.00 & $13.19 \pm 0.99$ & 1.00 \\
\hline \multirow[t]{3}{*}{0.002} & Cara & $2.80 \pm 0.12$ & 0.99 & $3.22 \pm 0.13^{* *}$ & 0.39 & $12.95 \pm 0.87^{* *}$ & 0.60 \\
\hline & Cara $\times$ Scant 3 & $3.56 \pm 0.22$ & 0.93 & $11.17 \pm 1.34$ & 0.98 & $15.07 \pm 1.41^{*}$ & 0.75 \\
\hline & Scant 3 & $3.64 \pm 0.27$ & 0.95 & $8.56 \pm 1.00$ & 0.93 & $12.57 \pm 1.24$ & 0.95 \\
\hline \multirow[t]{3}{*}{0.01} & Cara & $2.81 \pm 0.14$ & 0.99 & $4.83 \pm 0.21^{* *}$ & 0.59 & $8.75 \pm 0.63^{* *}$ & 0.41 \\
\hline & Cara $\times$ Scant 3 & $3.25 \pm 0.31$ & 0.85 & $6.44 \pm 1.42$ & 0.57 & $11.69 \pm 1.81^{* *}$ & 0.58 \\
\hline & Scant 3 & $1.80 \pm 0.37^{* *}$ & 0.47 & $4.80 \pm 0.77 * *$ & 0.52 & $8.44 \pm 2.56^{*}$ & 0.64 \\
\hline & 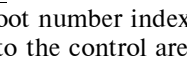 & cally & 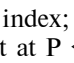 & $\mathrm{I}-$ roots 1 & & & \\
\hline
\end{tabular}

The strongest toxic effect of phosphomide on the primary root system appeared at a concentration of $0.01 \%$, when Cara variety showed the maximum sensitivity to the mutagen $(\mathrm{RLI}=0.41)$. In this variety, the shoot length reduced by $61.0 \%$ at a low mutagen concentration $(0.002 \%)$, while $0.01 \%$ concentration led to only a $41.0 \%$ decrease. In Scant 3 variety and Cara $\times$ Scant 3 hybrid, a higher toxic effect was observed at $0.01 \%$ mutagen concentration. Phosphomide did not stimulate root and shoot growth. The greatest inhibition of growth in the parental varieties and the hybrid was noted at a $0.01 \%$ mutagen concentration.

The germination energy in laboratory experiments and field germination are the criteria for assessing the sowing qualities of seeds. Mutagen at a concentration of $0.002 \%$ had a stimulating effect on seed germination rate in the hybrid form, and also contributed to germination energy in Cara which was $5.9 \%$ higher as compared to that of the best parent variety (Table 3).

3. Seed sensitivity (compared to control, \%) to different phosphomide concentrations in spring soft wheat (Triticum aestivum $L_{\text {.) }}$ parent varieties and $\mathbf{F}_{\mathbf{4}}$ hybrid estimated in $\mathbf{M}_{1}$ generation (Biostation of Tyumen State University, Tyumen region, 2014; field and laboratory experiments)

\begin{tabular}{l|l|c|c|c}
\hline Concentration, $\%$ & \multicolumn{1}{c|}{ Samples } & $\begin{array}{c}\text { Seed germination } \\
\text { energy }\end{array}$ & $\begin{array}{c}\text { Field seed } \\
\text { germination }\end{array}$ & $\begin{array}{c}\text { Biological } \\
\text { sustainability }\end{array}$ \\
\hline 0.01 & Cara & $75.0^{*}$ & $37.0^{*}$ & $27.0^{*}$ \\
& Cara $\times$ Scant 3 & $47.1^{*}$ & 90.0 & $180.0^{*}$ \\
0.002 & Scant 3 & $52.9^{*}$ & $64.9^{*}$ & $54.6^{*}$ \\
& Cara & 100.0 & 97.0 & $90.0^{*}$ \\
& Cara $\times$ Scant 3 & $105.9^{*}$ & $67.0^{*}$ & $114.0^{*}$ \\
* Differences to the cont 3 & $94.1^{*}$ & $82.4^{*}$ & $82.5^{*}$ \\
\hline
\end{tabular}

The control seeds of the varieties and hybrid were characterized by high field germination (97-100\%). A decrease in this index was noted in all variants with phosphomide, which may be due to violation in embryo development. Cara variety showed a high sensitivity to the mutagen at a concentration of $0.01 \%$. Biological sustainability of plants in this variant, calculated as the ratio of the number of plants that survived to harvest to the number of sown seeds, was very low $(27.0 \%)$. In the hybrid form, in contrast to the parental varieties, the toxic 
effect of high concentration on field germination was less pronounced, and the effect of stimulation was observed for biological stability. The increased resistance of $\mathrm{F}_{4}$ hybrid to the chemical mutagen could be due to heterozygosity associated with the hybrid origin or induced by phosphomide.

Quantitative trait expression, in the opinion of many researchers [24-27], depends on duration of vegetative period, plant length, resistance to lodging, and the sensitivity of photosynthetic apparatus to unfavorable environmental factors. The yield is the result of the complex interaction of the genotype with the environment [28-30].

We revealed an ambiguous plant response to the mutagen by seed production in $\mathrm{M}_{1}$. When the seeds were treated with phosphomide at a concentration of $0.01 \%$, the stimulatory effect in Cara $\times$ Scant 3 hybrid was manifested in a statistically significant increase of grain weight per $1 \mathrm{~m}^{2}$ by $16.0 \%$ compared to the control. Also, there was a significant decrease in seed production in Cara and Scant 3 varieties (by $67.0 \%$ and $57.0 \%$, respectively). The hybrid, which is more resistant to the chemical mutagen, as indicated by plant survival, also had higher grain weight compared to the original forms.

Parental and hybrid forms differed significantly in the prevalence $(\mathrm{P})$ of fungal diseases under natural infection. In 2013, wheat plants had no leaf damage caused by mildew pathogen Erysiphe graminis DC. and brown rust pathogen Puccinia recondita Rob. ex Desm. f. sp. tritici Eriks. (= P. triticina Eriks.). The prevalence of powdery mildew reached a maximum (100\%) in 2014.

The highest activity of spotting caused by Alternaria spp. and Helminthosporium spp. was recorded in $2013(\mathrm{P}=2-50 \%)$. In this case, the Cara $\times$ Scant 3 hybrid, when seeds were treated with phosphomide at a concentration of $0.01 \%$, had the lowest prevalence of spotting (Table 4).

4. Resistance of $M_{1}$ and $M_{2}$ generations of spring soft wheat (Triticum aestivum $L$.) parental varieties and $F_{4}$ hybrid to fungal diseases depending on seed treatment with different phosphomide concentrations (Biostation of Tyumen State University, Tyumen region, 2013-2014; field trial)

\begin{tabular}{|c|c|c|c|c|c|c|c|}
\hline \multirow{2}{*}{ Samples } & \multirow{2}{*}{$\begin{array}{l}\text { Concentration, } \\
\%\end{array}$} & \multicolumn{2}{|c|}{ Powdery mildew } & \multicolumn{2}{|c|}{ Brown rust } & \multicolumn{2}{|r|}{ Spotting } \\
\hline & & $\mathrm{P}, \%$ & Res & $\mathrm{P}, \%$ & Res & $\mathrm{P}, \%$ & Res \\
\hline \multicolumn{8}{|c|}{$\mathrm{M}_{1}(2013)$} \\
\hline \multirow[t]{3}{*}{ Cara } & Control & 0 & - & 0 & - & 30 & Very high \\
\hline & 0.002 & 0 & - & 0 & - & 5 & Very high \\
\hline & 0.01 & 0 & - & 0 & - & 10 & High \\
\hline \multirow[t]{3}{*}{ Cara $\times$ Scant 3} & Control & 0 & - & 0 & - & 40 & High \\
\hline & 0.002 & 0 & - & 0 & - & 40 & Very high \\
\hline & 0.01 & 0 & - & 0 & - & 2 & Very high \\
\hline \multirow[t]{3}{*}{ Scant 3} & Control & 0 & - & 0 & - & 40 & High \\
\hline & 0.002 & 0 & - & 0 & - & 30 & High \\
\hline & 0.01 & 0 & - & 0 & - & 50 & High \\
\hline \multicolumn{8}{|c|}{$\mathrm{M}_{2}(2014)$} \\
\hline \multirow[t]{3}{*}{ Cara } & Control & 100 & High & 50 & Very high & 30 & Very high \\
\hline & 0.002 & 100 & High & 50 & Very high & 30 & Very high \\
\hline & 0.01 & 100 & Low & 100 & Low & 5 & Very high \\
\hline \multirow[t]{3}{*}{ Cara $\times$ Scant 3} & Control & 100 & Medium & 100 & Very high & 5 & Very high \\
\hline & 0.002 & 100 & Low & 50 & Very high & 10 & Very high \\
\hline & 0.01 & 100 & High & 100 & Low я & 3 & Very high \\
\hline \multirow[t]{3}{*}{ Scant 3} & Control & 100 & Medium & 100 & Low & 5 & Very high \\
\hline & 0.002 & 100 & Medium & 100 & Low & 5 & Very high \\
\hline & 0.01 & 100 & Low & 100 & Low & 10 & Very high \\
\hline
\end{tabular}

A full picture of plant resistance to leaf phytopathogens can be obtained by determining the damage and disease development indices (R), calculated based on accounting sick and healthy plants and the damage score. Four groups were distinguished by disease development indices: very high resistance $(\mathrm{R}=0$ $20 \%)$, high resistance $(\mathrm{R}=21-40 \%)$, medium resistance $(\mathrm{R}=41-60 \%)$, low 
resistance ( $\mathrm{R}=61-80 \%)$. In $\mathrm{M}_{2}$ generations of parental varieties, there was a decrease in resistance to powdery mildew and brown rust pathogens from high and medium in the control to low at $0.01 \%$ mutagen concentration. Under the influence of a high phosphomide concentration the hybrid susceptibility to powdery mildew decreased and to brown rust increased. The plants in the control and after the application of phosphomide showed high and very high resistance to spotting (Table 4).

In general, our laboratory and field experiments showed that phosphomide had activity similar to that of nitrosoethylurea and dimethyl sulfate supermutagens at $0.01,0.02 ; 0.03$ and $0.05 \%$ concentrations, which we studied earlier on Truggve, WW 5530 and WW 6110 winter wheat varieties from Sweden [8]. The data obtained suggest that the phosphomide can be used in mutagenesis and spring soft wheat breeding. The role of experimental mutagenesis is confirmed by the creation in the world of more than 3000 varieties of different crops [31].

Thus, 0.002 and $0.01 \%$ phosphomide concentrations effectively generated mutant plants in the spring soft wheat varieties and the intraspecies hybrid. Treating seeds with phosphomide led to a strong inhibitory effect on germination and morphometric parameters in seedlings which depended on the mutagen dose, and increased plant viability during the growing season. The hybrid Cara $\times$ Scant 3 had an advantage over the parents on seed production. Mutagen concentration of $0.01 \%$ generated an increase in plant resistance to powdery mildew. A lower sensitivity to the mutagen in $\mathrm{M}_{1}$ and a greater frequency and variety of mutants in $\mathrm{M}_{2}$ were characteristic of the hybrid as compared to the parental varieties. There was no clear correlation between the susceptibility of varieties and the hybrid to phytopathogenic fungi and phosphomide concentrations. Differences in response to the mutagenic factor between the initial varieties and the hybrid form were due to the genotypic features of the varieties and to heterosis and heterozygosity of the hybrid. This can positively result in high adaptability which provides increased adaptation to unfavorable environmental conditions in newly created wheat varieties.

\section{REFERENCES}

1. A l e k s a n y a n S.M. Trudy po prikladnoi botanike, genetike i selektsii, 2007, 164: 11-33 (in Russ.).

2. Sovremennye metody $i$ mezhdunarodnyi opyt sokhraneniya genofonda dikorastushchikh rastenii (na primere dikikh plodovykh). Kollektivnaya monografiya [Relevant methods and international experience in preserving wild fruit plants: a collective monograph]. Almaaty, 2011 (in Russ.).

3. Konventsiya o biologicheskom raznoobrazii [Biodiversity Convention]. Available https://www.cbd.int/undb/media/factsheets/undb-factsheets-ru-web.pdf. Accessed June 01, 2016 (in Russ.).

4. R a p o p o r t I.A. Mikrogenetik [Microgenetics]. Moscow, 2010 (in Russ.).

5. Po p o lz u k i n a N.A. Selektsiya yarovoi myagkoi pshenitsy v usloviyakh Zapadnoi Sibiri na osnove sochetaniya indutsirovannogo mutageneza i gibridizatsii. Avtoreferat doktorskoi dissertatsii [Combination of induced mutagenesis and crosses for soft wheat breeding in West Siberia. DSc Thesis]. Tyumen', 2004 (in Russ.).

6. K r o t o v a L.A. Vestnik Altaiskogo gosudarstvennogo universiteta, 2009, 9: 12-15 (in Russ.).

7. B o m e N.A., B o m e A.Ya. V sbornike: Indukovanii mutagenez $v$ selektsiï roslin [Induced mutagenesis in plant breeding]. Bila Tserkva, 2012: 53-60 (in Russ.).

8. B o m e N.A. Estestvennye i tekhnicheskie nauki, 2014, 11-12(78): 126-129 (in Russ.).

9. Morgun V.V., Kat e ri n c huk A.M., Chugu n k o va T.V. Izvestiya Samarskogo nauchnogo tsentra Rossiiskoi akademii nauk, 2013, 15(3/5): 1666-1669 (in Russ.).

10. Meng Q., Redetzke D.L., H a ckfeld L.C., Hodge R.P., Walke r D.M., Wa $1 \mathrm{k}$ e r V.E. Mutagenicity of stereochemical configurations of 1,2-epoxybutene and 1,2:3,4-diepoxybutane in human lymphoblastoid cells. Chem.-Biol. Interact., 2007, 166(1-3): 207-218 (doi: 10.1016/j.cbi.2006.06.001).

11. Plant mutation breeding and biotechnology. Q.Y. Shu, B.P. Forster, H. Nakagawa (eds.). Plant Breeding and Genetics Section, Joint FAO/IAEA Division of Nuclear Techniques in Food and Agriculture, International Atomic Energy Agency, Vienna, Austria, 2012 (doi: 10.1079/9781780640853.0000). 
12. We is f e ld L.I. About cytogenetic mechanism of chemical mutagenesis. In: Ecological consequences of increasing crop productivity. Plant breeding and biotic diversity. A.I. Opalko, L.I. Weisfeld, S.A. Bekuzarova, N.A. Bome, G.E. Zaikov (eds.). Toronto-New Jersey, Apple Academic Press, 2015: 259-269.

13. Gradchaninova O.D., Filat e nko A.A., Rud e nko M.N. Metodicheskie ukazaniya po izucheniyu mirovoi kollektsii pshenitsy [World wheat collection study: Guidelines]. Leningrad, 1987 (in Russ.).

14. D o r of e v V.F., La ptev Yu.P., Che kali n N.M. Tsvetenie, opylenie $i$ gibridizatsiya rastenii [Plant flowering, pollination and crossing]. Moscow, 1990 (in Russ.).

15. GOST 12038-84. Semena sel'skokhozyaistvennykh kul'tur. Metody opredeleniya vskhozhesti [RF State Standard 12038-84. Crop seeds. Estimation of germination rate]. Moscow, 2011 (in Russ.).

16. Gritsenko V.V., Orekhov D.A., Popov S.Ya., Stroikov Yu.M., Tret'yak o v N.N., S h k a li k o v V.A. Zashchita rastenii [Plant protection]. Moscow, 2005 (in Russ.).

17. Popkova K.V., Shkalikov V.A., Stroikov Yu.M., Le k o m t s e va S.N., Skvort s o v a I.N. Obshchaya fitopatologiya [General phytopathology]. Moscow, 2005 (in Russ.).

18. B o m e N.A., Ri p b e rge r E.I., Traut s D. Ekologiya i prirodopol'zovanie, 2015, 1(1): 98107 (in Russ.).

19. G ri n val'd K. V sbornike: Eksperimental'nyi mutagenez $v$ selektsii [Experimental mutagenesis in breeding]. Moscow, 1972: 333-347 (in Russ.).

20. M a c K e y I. Mutation breeding in polyploid cereals. Acta Agr. Scand., 1954, 3(4): 543-555.

21. G ris h k o V.N. Visnik Dnipropetrovs'kogo universitetu. Biologiya. Ekologiya, 2008, 16(1): 64-67 (in Russ.).

22. K a r m a n e n k o N.M. Response to low temperature, soil acidification and aluminium in the varieties of cereal crops. Agricultural Biology, 2014, 5: 66-77 (doi: 10.15389/agrobiology.2014.5.66rus) (in Russ.).

23. D i k a r e v A.V., D i k a re v V.G., D i k a r e va N.S. Agrokhimiya, 2014; 7: 45-52 (in Russ.).

24. Mathews K.L., Chapman S.C., Trethowan R., Singh R.P., C rossa J., Pfe iffer W., van Ginkel M., D e Lacy I. Global adaptation of spring bread and durum wheat lines near-isogenic for major reduced height genes. Crop Sci., 2006, 46(2): 603-613 (doi: 10.2135/cropsci2005.05-0056).

25. M a ri as R.R., Go n c a lves J.F.C., S a n tos Jr. U.M., D ü n is ch O., S a n tos A.L.W. Chloroplastid pigment contens and chlorophyll a fluorescence in Amazonian tropical three species. Revista Arvore, 2007, 31(5): 959-966 (doi: 10.1590/S0100-67622007000500020).

26. M a lchikov P.N., M y a s nikova M.G. Approaches to the development of durum wheat cultivars (Triticum durum Desf.) with a wide variability of the growth season. Russian Journal of Genetics: Applied Research, 2016, 6(3): 249-257 (doi: 10.1134/S2079059716030072).

27. Ri p b e rge $\mathrm{r}$ E.I., B o m e N.A., Tra u z D. Variation in the plant height of spring common wheat (Triticum aestivum L.) hybrid forms under different ecological and geographical conditions. Russian Journal of Genetics: Applied Research, 2016, 3(6): 258-263 (doi: 10.1134/S2079059716030102).

28. Gaju O., Reynolds M.P., Sparces D.L., Foulkes M.E. Relationships between large-spike phenotype, grain number, and yield potential in spring wheat. Crop Sci., 2009, 49(3): 961-973 (doi: 10.2135/cropsci2008.05.0285).

29. Knezevic D., Ze cevic V., Stamenkovic S., Milosevic B. Variability of number of kernels per spike in wheat cultivars (Triticum aestivum L.). Journal of Central European Agriculture, 2012, 13(3): 608-614 (doi: 10.5513/JCEA01/13.3.1099).

30. Protich R., Nodorovich G., Protich N. Grain weight per spike of wheat using different ways of seed protection. Bulgarian Journal of Agracultural Science, 2012, 18(2): 185-190.

31. Nuclear safety review for the year 2009. IAEA, Austria. Available https://www.iaea.org/About/Policy/GC/GC54/GC54InfDocuments/English/gc54inf-2_en.pdf. Accessed June 20, 2017.

\section{Events \\ THE INTERNATIONAL SOCIETY FOR ECOLOGICAL MODELLING GLOBAL CONFERENCE 2017}

(17-21 September 2017, Ramada Plaza, Jeju, Korea)

General sessions: ecology in molecules and cells; individual ecology in relation with physiology, morphology, behavior, etc; population and community ecology; ecosystem functioning and management (e.g., energy, bio-geo-chemical cycle); food-energy-water nexus

Information: https://www.elsevier.com/events/conferences/international-society-for-ecologicalmodelling-global-conference 